\title{
Use of skeletochronological analysis to estimate the age of leatherback sea turtles Dermochelys coriacea in the western North Atlantic
}

\author{
Larisa Avens ${ }^{1, *}$, J. Christopher Taylor ${ }^{2}$, Lisa R. Goshe ${ }^{1}$, T. Todd Jones ${ }^{3}$, \\ Mervin Hastings ${ }^{3,4}$
}

${ }^{1}$ NOAA Fisheries, Southeast Fisheries Science Center, Center for Coastal Fisheries and Habitat Research, 101 Pivers Island Road, Beaufort, North Carolina 28516, USA

${ }^{2}$ National Ocean Service, Center for Coastal Fisheries and Habitat Research, 101 Pivers Island Road, Beaufort, North Carolina 28516, USA

${ }^{3}$ University of British Columbia, Department of Zoology, 6270 University Blvd., Vancouver, British Columbia V6T 1Z4, Canada

${ }^{4}$ Conservation and Fisheries Department, Ministry of Natural Resources and Labour, Government of the British Virgin Islands, Road Town, Tortola, British Virgin Islands

\begin{abstract}
Although growth rate and age data are essential for leatherback management, estimates of these demographic parameters remain speculative due to the cryptic life history of this endangered species. Skeletochronological analysis of scleral ossicles obtained from 8 captive, known-age and 33 wild leatherbacks originating from the western North Atlantic was conducted to characterize the ossicles and the growth marks within them. Ages were accurately estimated for the known-age turtles, and their growth mark attributes were used to calibrate growth mark counts for the ossicles from wild specimens. Due to growth mark compaction and resorption, the number of marks visible at ossicle section tips was consistently and significantly greater than the number visible along the lateral edges, demonstrating that growth mark counts should be performed at the tips so that age is not underestimated. A correction factor protocol that incorporated the trajectory of early growth increments was used to estimate the number of missing marks in those ossicles exhibiting resorption, which was then added to the number of observed marks to obtain an age estimate for each turtle. A generalized smoothing spline model, von Bertalanffy growth curve, and size-at-age function were used to obtain estimates of age at maturity for leatherbacks in the western North Atlantic. Results of these analyses suggest that median age at maturation for leatherbacks in this part of the world may range from 24.5 to $29 \mathrm{yr}$. These age estimates are much greater than those proposed in previous studies and have significant implications for population management and recovery.
\end{abstract}

KEY WORDS: Sea turtle $\cdot$ Leatherback $\cdot$ Dermochelys coriacea $\cdot$ Skeletochronology $\cdot$ Skeletal growth mark $\cdot$ Line of arrested growth $\cdot$ LAG

\section{INTRODUCTION}

Knowledge of juvenile stage durations, age at maturation, and reproductive longevity are essential for understanding the life history of any organism (Stearns 1992). Furthermore, the ability to relate age to reproductive effort is integral to studies of population dynamics, which in turn can inform management strategies for those organisms considered at risk
(Sæther et al. 1996, Chaloupka \& Musick 1997, Heppell et al. 2003a). Given the Vulnerable and Endangered status of most sea turtle populations worldwide (IUCN 2008), the need for age data to accurately characterize the status of these species is vital for conservation efforts (Heppell et al. 2003a,b).

Historically, studies of sea turtle age and growth have predominantly focused on cheloniid sea turtle species such as green turtles Chelonia mydas and log- 
gerheads Caretta caretta. As this field of research has developed, our understanding of the time frames over which individual marine turtles exist has undergone a significant transformation. Early on, these marine turtles were thought to possibly transition from hatchlings to mid-sized juveniles within a single year (Carr 1967). Extrapolation of short-term, rapid growth rates observed for captive juvenile sea turtles (Caldwell 1962, Uchida 1967, Hirth 1971) and wild turtles during the summer growing season (Mendonça 1981) suggested ages at maturation ranging from 4 to $15 \mathrm{yr}$.

Subsequent growth rate data obtained from captive marine turtles reared under semi-wild conditions (Frazer \& Schwartz 1984) and wild mark-recapture studies conducted over longer time scales (Limpus 1979, Limpus \& Walter 1980, Frazer \& Ehrhart 1985, Braun-McNeill et al. 2008) indicated greater time to maturation than previously thought. Similarly, skeletochronology (the analysis of skeletal growth marks) has been applied to obtain age data (Zug et al. 1986, 1995, 2002, Klinger \& Musick 1995, Parham \& Zug 1997, Zug \& Glor 1998, Snover 2002, Snover \& Rhodin 2008), often resulting in markedly increased estimates of stage durations and age at maturity. For loggerhead and green turtles, the 'lost year' has been revealed to be the 'lost years'; estimates of oceanic stage duration range from 8 to $14 \mathrm{yr}$ for loggerhead (Snover 2002, Bjorndal et al. 2003) and 3 to 6 yr for green turtles (Zug \& Glor 1998). Predictions of age at maturation for these species now range from 30 to $40 \mathrm{yr}$ (Limpus 1979, NMFS SEFSC 2001, Snover 2002, Zug et al. 2002, Heppell et al. 2003b) and are as high as 40 to $50 \mathrm{yr}$ in the case of Hawaiian green turtles (Balazs \& Chaloupka 2004).

Despite the advances made with cheloniid marine turtles, estimates of the time required for $6 \mathrm{~cm}$ leatherback sea turtle Dermochelys coriacea hatchlings (van Buskirk \& Crowder 1994) to grow into 145 $\mathrm{cm}$ or greater adults (TEWG 2007) range widely. Whereas early analyses extrapolating the rapid growth rates observed for captive turtles yielded 2, 3, or 6 yr to maturity (Deraniyagala 1952, Birkenmeier 1971, Bels et al. 1988), more recent captive growth data indicate that leatherbacks may not mature until 12 to $18 \mathrm{yr}$ of age (Jones 2009). The presence of vascularized cartilage in leatherback limb bones, a characteristic associated with rapid growth and more typical of endotherms, has suggested the potential for early maturation, perhaps between 3 and 6 yr of age (Rhodin 1985, reviewed by Snover \& Rhodin 2008). However, genetic analyses describing possible mother-daughter relationships in a Caribbean nesting population estimate 12 to 14 yr to maturation (Dutton et al. 2005).

Skeletochronological analysis of putative growth marks observed at the lateral edge of sectioned scleral ossicles (small bones surrounding the pupil of the eye; see Fig. 1) yielded an average age at maturation of 13 to 14 yr for Pacific leatherbacks (Zug \& Parham 1996). Subsequent analyses have supported the hypothesis that marks in the scleral ossicles of loggerhead and Kemp's ridley sea turtles represent annual cycles (Avens \& Goshe 2007). However, these analyses also demonstrated that, due to lateral growth mark compression and central resorption, growth mark counts taken at ossicle section tips are far greater than those obtained laterally, suggesting that leatherback age might previously have been underestimated (Avens \& Goshe 2007).

Here, we present a skeletochronological analysis of scleral ossicles obtained from leatherbacks in the western North Atlantic Ocean, to further characterize these structures and the growth marks within them. We analyzed ossicles from captive-reared leatherbacks of known age to calibrate interpretation of the deposition pattern and frequency of growth marks in the ossicles of wild turtles. We then analyzed ossicles obtained from wild leatherbacks to estimate age at maturation for the species in this region.

\section{MATERIALS AND METHODS}

Sample collection. From 2001 to 2008, scleral ossicles were obtained from leatherback sea turtles that stranded dead, were debilitated and later euthanized, or died in the course of permitted research; no turtles were purposefully sacrificed in the course of the present study. Eight juvenile leatherbacks obtained as hatchlings from the British Virgin Islands (Lambert's Bay Beach: $18.4167^{\circ} \mathrm{N}, 64.5833^{\circ} \mathrm{W}$ ) that were part of a captive rearing study (Jones 2009) died in the course of this research between 0.10 and $1.41 \mathrm{yr}$ of age (mean \pm $\mathrm{SD}, \overline{\mathrm{X}}=0.79 \pm 0.51 \mathrm{yr}$ ). These turtles were reared indoors under a combination of ambient and full-spectrum fluorescent lighting, with water temperature maintained at $24 \pm 1^{\circ} \mathrm{C}$ and salinity at 28 to $33 \mathrm{ppt}$ (Jones 2009). One eye was collected from each of the sea turtles, along with straight line carapace length (SCL) as measured in $\mathrm{cm}$ from the nuchal notch of the carapace to the tip of the caudal peduncle (9.71 to $34.7 \mathrm{~cm}, \overline{\mathrm{X}}=28.1 \pm 15.6 \mathrm{~cm})$.

For each wild, stranded sea turtle, participants in the national Sea Turtle Stranding and Salvage Network (STSSN) collected either one or both eyes. Observers typically recorded curved carapace length (CCL) and whenever possible, necropsies were conducted to ascertain sex. For analyses necessitating direct comparison of carapace length for both captive and wild leatherbacks, CCL for wild sea turtles was converted to SCL using the following formula derived from 17 sea turtles for which both CCL and SCL were available: 
$\mathrm{SCL}=0.9781 \mathrm{CCL}-0.7714\left(\mathrm{r}^{2}=0.9982\right)$. Samples were obtained from a total of 33 wild leatherbacks: 6 hatchlings, 2 small juveniles (16.6 and $27.3 \mathrm{~cm}$ CCL), and 25 large juveniles and adults ranging from 122 to $173 \mathrm{~cm}$ CCL ( $\bar{X}=147.5 \pm 13.9$ ). Of the larger sea turtles, 10 were female, 9 male, and 6 were of unknown sex. With the exception of 1 leatherback stranded in the Gulf of Mexico, the remainder were distributed along the US Atlantic coast as follows: Massachusetts (7), New Jersey (2), Virginia (2), North Carolina (11), South Carolina (1), and Florida (9, including the 6 hatchlings).

Sample processing. Ossicles were dissected from surrounding tissue, maintaining position within the ossicle ring in cases where the orientation of the eye relative to the head was known. After all ossicles had been removed from a given eye, they were photographed using a digital camera with a macro lens (Canon EOS 10D digital camera with Canon Telephoto EF $100 \mathrm{~mm}$ f/2.8 USM Macro Autofocus lens) before further processing, to document the characteristics of individual ossicles and the entire ring (Fig. 1). Ossicles were then immersed alternately in tap water and a 1:1 bleach:water solution and gently scraped with a metal probe to remove any remaining tissue.

Ossicles were fixed in $10 \%$ neutral buffered formalin (Fisher Scientific), rinsed in tap water, decalcified by immersion in RDO (Apex Engineering Corporation), and then allowed to soak in water overnight to remove any decalcifier remaining in the tissue. A freezing stage microtome (Leica Microsystems) was used to obtain $25 \mu \mathrm{m}$ thick sections (plane of sectioning shown in Fig. 1), which were stained using modified Mayer's hematoxylin (Myrick et al. 1983). Stained sections were mounted in $100 \%$ glycerin on microscope slides under glass coverslips sealed with Cytoseal 280 (Thermo Fisher Scientific).

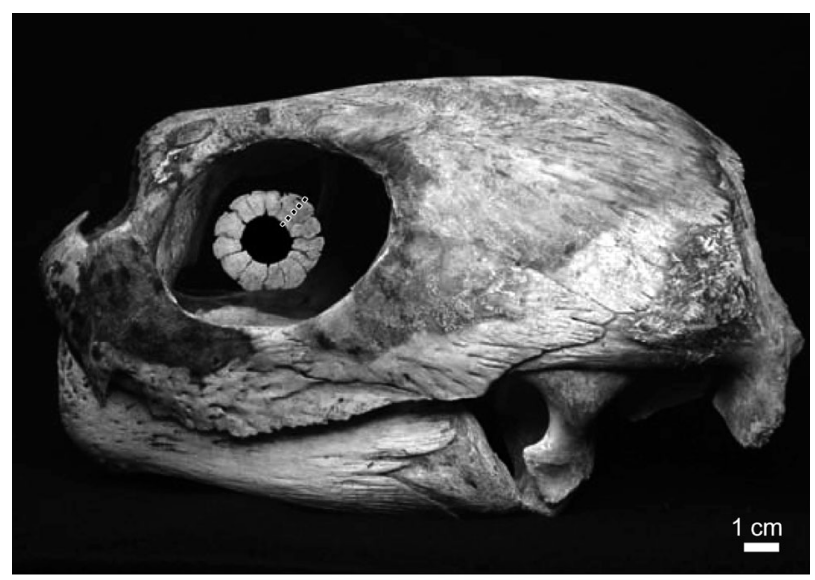

Fig. 1. Dermochelys coriacea. Leatherback skull, showing location of ossicle ring. Dashed line through ossicle denotes plane of sectioning
Analysis. Hematoxylin-stained ossicle sections were viewed under a trinocular compound microscope (Olympus BX41, OPELCO) at $10 \times$ magnification. Sequential, partial digital images of each ossicle were obtained using a Colorcube-12 Color CCD, 1.4 megapixel digital camera (OPELCO) and then stitched together in Adobe Photoshop LE (Adobe Systems) to form a high-magnification composite image to be used for further analysis. Ossicle and growth mark measurements were obtained using Microsuite Basic image analysis software (OPELCO). For comparisons of growth mark counts and measurements, the MannWhitney $U$-test was used when sample sizes differed, and the Wilcoxon test was applied to pair-wise comparisons (Zar 1996). Relationships between ossicle and carapace lengths were compared among wild and captive turtles, accounting for multiple ossicle measurements within individuals by using unbalanced repeated measures.

Counts of lines of arrested growth (LAGs), which delimit the outer boundaries of skeletal growth marks (Castanet et al. 1993), were conducted by a single observer (L. Avens). Initial examination of the wide tips of ossicles obtained from wild, stranded leatherbacks revealed a large number of marks whose deposition appeared to follow a distinct pattern: one or more lighter, diffuse marks followed by a darker, distinct mark (Fig. 2). It seemed unlikely that each of these marks represented an annual cycle, as this would have resulted in unexpectedly high age estimates (e.g. 63 marks observed for a $156 \mathrm{~cm}$ CCL female, just above the mean size for nesting females).

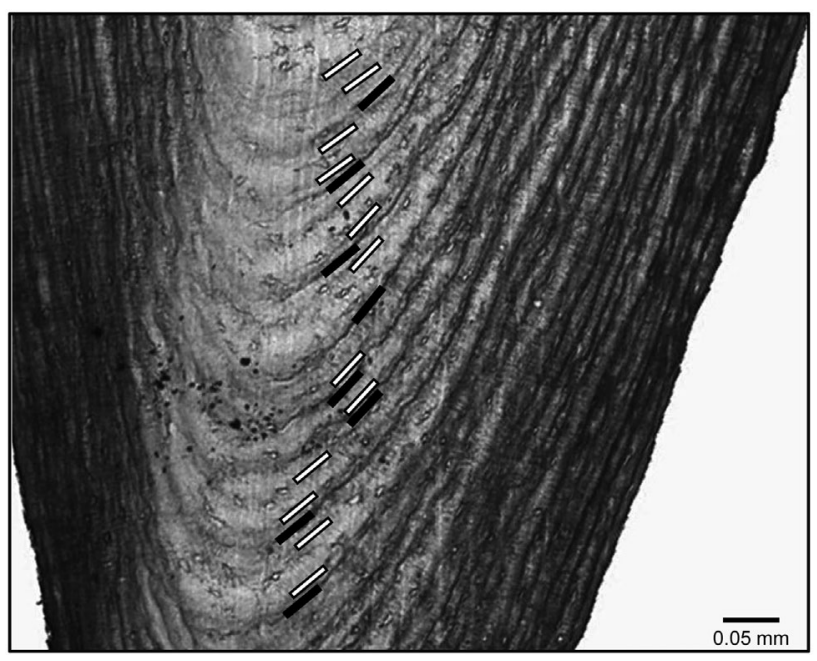

Fig. 2. Dermochelys coriacea. Partial, high-magnification $(10 \times)$ image of wide ossicle tip obtained from a leatherback $156 \mathrm{~cm}$ in curved carapace length, showing alternating diffuse light (white bars) and well-defined dark (black bars) lines of arrested growth 
Although the small size of the ossicles sometimes made it difficult to resolve the fine-scale pattern of LAG deposition, concurrent skeletochronological analysis of larger leatherback phalanges (finger bones) processed using the same methods as for sea turtle humeri (Avens \& Goshe 2007) revealed remarkable spatial consistency for the LAG groupings (Fig. 3). Such a regular pattern would not be expected if the marks were deposited as a result of sporadic events such as prey scarcity or harsh environmental conditions. Therefore, for the purpose of these analyses, we instead hypothesize that the LAG groupings result from the repeated, multiple migrations undertaken by North Atlantic leatherbacks each year among breeding/nesting areas and various foraging areas around the ocean basin (e.g. Hays et al. 2004, Eckert 2006). Growth mark deposition corresponding with migrations has been found in North Atlantic tuna species (Compeán-Jimenez \& Bard 1983). Also, annual cycles are reflected as multiple marks in the hard structures of many vertebrates (Casselman 1983, Klevezal 1996, Hohn

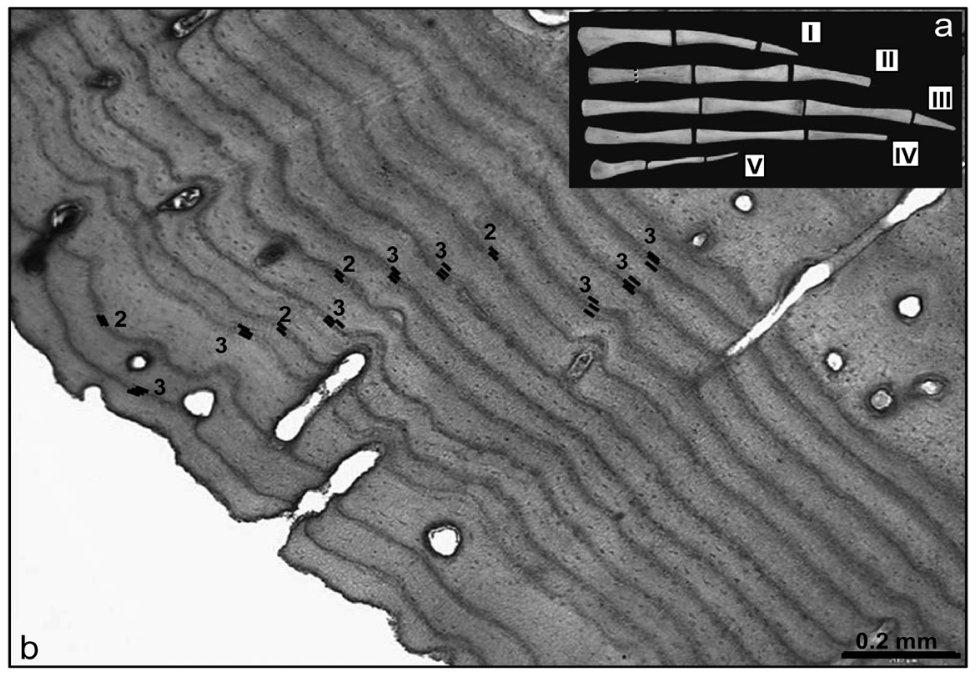

Fig. 3. Dermochelys coriacea. (a) Phalanges from right, front flipper of a leatherback $144.5 \mathrm{~cm}$ in curved carapace length. Roman numerals signify phalange number; phalanges in 'I' constitute the group of fingerbones positioned closest to the flipper's anterior edge. Dashed line in 'II' denotes plane of sectioning. (b) Partial image of phalange section $(4 \times)$ demonstrating spatial regularity of line of arrested growth groupings. Black lines and corresponding numbers denote the location and number of marks within growth mark groups
2002, Cailliet et al. 2006). Based on these findings, each LAG group was conservatively counted as 1 annual mark, delimited by the dark, distinct LAG, and these counts were used to obtain our age estimates. Independent counts were done both laterally and at the wide tips of ossicle sections (Fig. 4) at 5 d intervals or longer, until a consensus count was obtained (within 3 or 4 counts). Average percent error was calculated for these counts as described by Beamish \& Fournier (1981).

Ossicles from the 8 captive leatherbacks were analyzed without prior knowledge of age. Ages assigned through skeletochronology were then compared with actual ages, and the appearance of the annual marks in the ossicles of the known-age leatherbacks were then used to characterize early marks deposited in the ossicles of the wild turtles.

Although some wild leatherback ossicles exhibited no resorption, and age for these turtles could be calculated directly from LAG counts, in many ossicles resorption had destroyed early LAGs. The correction factor protocol described by Zug \& Parham (1996) was used to calculate the number of lost marks. This involved measuring LAGs throughout those wild ossicles in our sample exhibiting little to no resorption, in order to characterize early LAG growth patterns. Total LAG lengths could not be measured because lateral LAG compression made it impossible to follow marks around their entire circumference; therefore, LAG radii were measured instead (Fig. 4). The relationship between LAG number and LAG radius was then modeled to predict the number of missing LAGs in each resorption core, which was added to the observed number of LAGs to yield an age estimate for each turtle.

Median ages at maturation were estimated assuming 3 carapace lengths reported for nesting female leatherbacks in the western North Atlantic (Stewart et al. 2007, TEWG 2007): (1) $125 \mathrm{~cm}$ as the minimum size; (2) $145 \mathrm{~cm}$ as the average size at first nesting; and (3) $155 \mathrm{~cm}$ as the average size of nesting females. Sex-specific analyses were not conducted due to the large number of unknown-

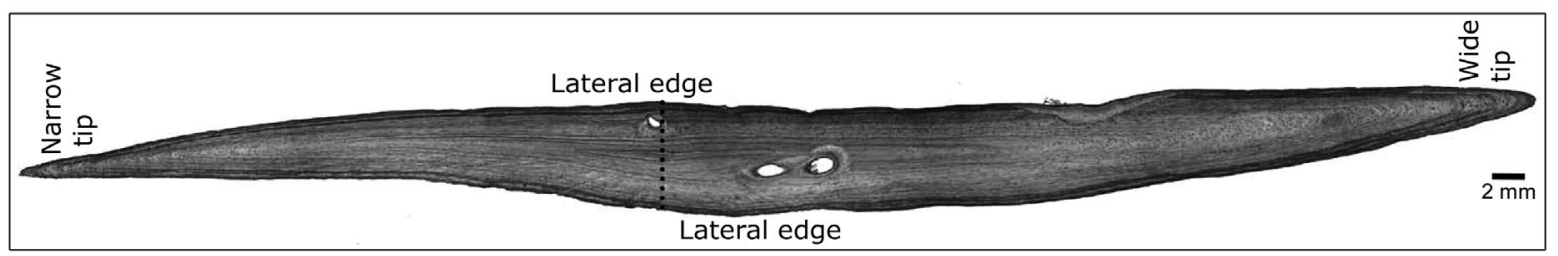

Fig. 4. Dermochelys coriacea. Entire ossicle section showing lateral edges, and narrow and wide tips. Growth mark and/or line of arrested growth radius measurements were taken starting from the location of the dotted line, which represents the average location of the core mark center relative to the wide tip (proportionally 0.56 total ossicle length) 
sex turtles in the sample. Two methods were used to model the growth of leatherbacks. First, size at estimated age was fit using a non-parametric smoothing spline model and a von Bertalanffy growth curve. Smoothing splines were fit using the generalized crossvalidation procedure to optimize the fit, while minimizing the chance of oversmoothing (Wood 2001), and confidence regions were generated using Bayesian posterior probabilities. Second, a parametric model was fit to the data adopting the following form of the von Bertalanffy growth model:

$$
\mathrm{CCL}=L_{\infty}\left\{1-e^{\left[-k\left(\text { Age }-t_{0}\right)\right]}\right\}
$$

where CCL is the curved carapace length, $L_{\infty}$ is the maximum length, $k$ is the intrinsic growth rate, and $t_{0}$ is the intercept parameter (von Bertalanffy 1938). The model was fit using non-linear least squares; confidence regions were constructed using a delta method for estimating uncertainty using the means and variance-covariance matrix of parameter estimates. As an alternative method to characterize uncertainty, we estimated model parameters and model predictions by randomly resampling from the data with replacement (bootstrap), and refitting the von Bertalanffy model to the sample data 10000 times. To maintain general consistency in the shape of the fitted model, we assumed that each resampling would contain a hatchling (age = 0, carapace length $=6 \mathrm{~cm}$; van Buskirk \& Crowder 1994). Confidence regions were calculated using the central $95 \%$ of the predictions of size at estimated age. For both the smoothing spline and von Bertalanffy models, predictions were generated and estimated ages were determined that included the assumed size at maturation (i.e. 125, 145, and $155 \mathrm{~cm} \mathrm{CCL)} \mathrm{within}$ the $95 \%$ confidence regions.

Finally, an age-maturation function was estimated using a generalized smoothing spline logistic model incorporating estimated ages and assumed sizes of mature nesting females (where individuals greater than assumed size are considered mature). The generalized smoothing spline was fit and confidence bounds estimated using Bayesian posterior probabilities (Bishop et al. 2006, Zug et al. 2006).

\section{RESULTS}

Ossicle rings from leatherbacks for which we received entire eyes contained between 10 and 13 ossicles $(\overline{\mathrm{X}}=12.1 \pm 1.1, \mathrm{n}=29)$. The relationship between SCL and ossicle length (OL) was linear and there was no significant difference between the slopes for wild and captive leatherbacks ( $p>0.70)$. The equation describing the grouped data was $\mathrm{OL}=0.0551 \mathrm{SCL}$ $+1.472\left(\mathrm{r}^{2}=0.9216\right)$.

Preliminary observations using stained sections from all ossicles within individual eyes and/or rings revealed a great deal of variation in the amount of resorption;

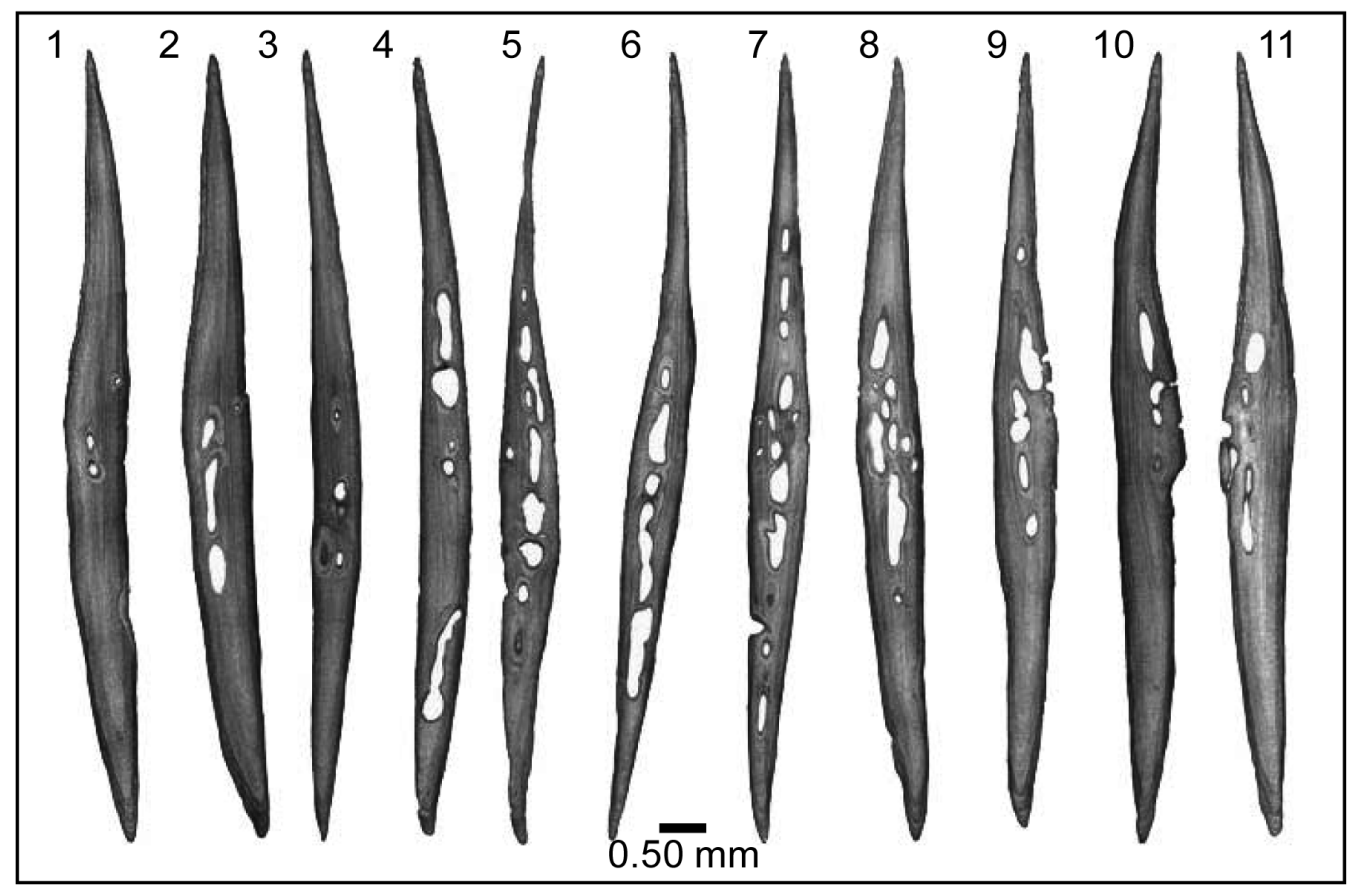

Fig. 5. Dermochelys coriacea. Sections of all ossicles from a single eye, displaying resorption levels ranging from minimal (e.g. ossicle 1) to extensive (ossicle 5) 
whereas some ossicles exhibited little to no growth mark resorption, others were almost entirely remodeled, with few LAGs remaining (Fig. 5). For those ossicle rings where orientation relative to the head was known $(\mathrm{n}=$ 13), no significant relationship was found between ossicle position and the number of retained LAGs $\left(\mathrm{r}^{2}=0.004\right.$, $\mathrm{p}>0.20, \mathrm{n}=159$ ossicles). This lack of predictive power made it necessary to process every ossicle from each sea turtle to ensure that the best ossicle (i.e. that with the least resorption) was found and analyzed.

The ossicles with little to no resorption at the center contained a distinct mark (Fig. 6) similar to the core mark described for Kemp's ridley and loggerhead sea turtles (Avens \& Goshe 2007) and which appears to be deposited at hatching for these species. Comparison of leatherback core mark and leatherback hatchling ossicle lengths revealed no significant difference (MannWhitney $U$-test, $\mathrm{p}>0.20, \mathrm{n}=12$ hatchling ossicles, $\mathrm{n}=$ 11 core marks), indicating that the leatherback core mark is also a hatch mark and should be used as the starting point for estimating age, representing age 0 .

Average percent error for grouped growth mark counts was $4 \%$. Comparison of LAG counts made laterally with those from the wide tips of ossicle sections revealed a highly significant difference (Wilcoxon paired sample test, $\mathrm{p}<0.0005, \mathrm{n}=18$ ). Without excep-
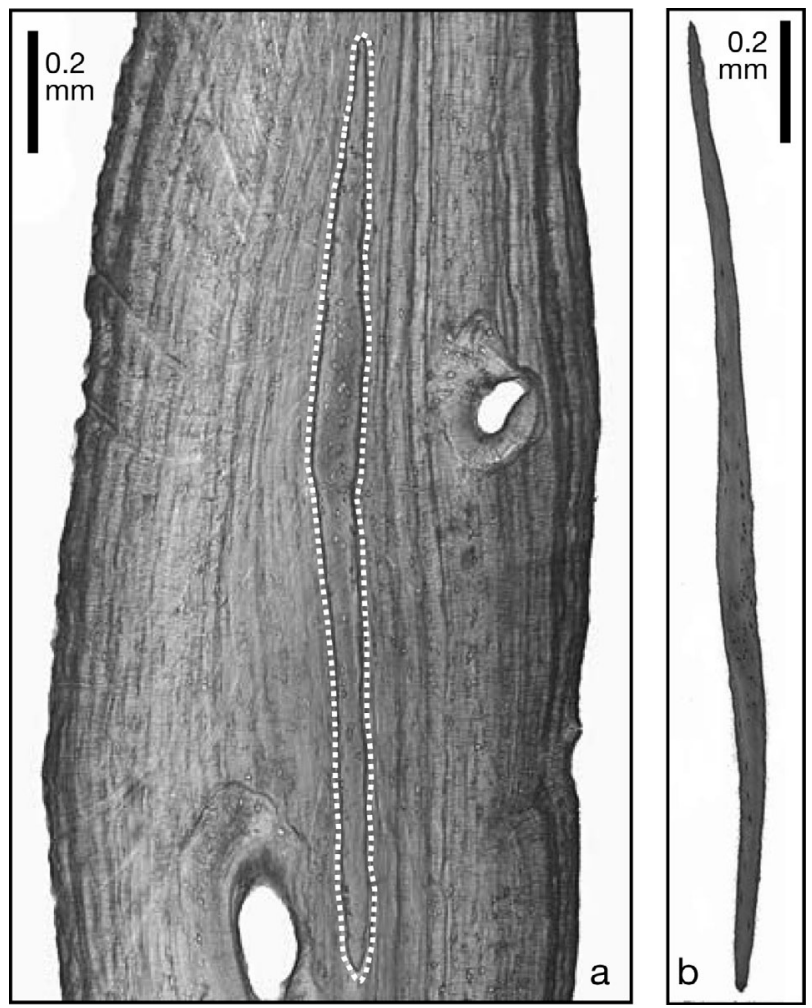

Fig. 6. Dermochelys coriacea. (a) Core mark (dotted line) observed at the center of those ossicles exhibiting little to no resorption. (b) Hatchling ossicle section tion, a greater number of marks was visible at the wide tip and therefore all counts used for age analyses were obtained from this region.

Age was accurately predicted for the 8 known-age, captive-reared leatherbacks and this allowed characterization of the first annual LAG (LAG 1), which was the first faint, but complete, mark that could be followed continuously starting at the lateral edges down through the wide tip (Fig. 7a). Similar marks outside the core marks were observed in those wild leatherback ossicles that exhibited little resorption (Fig. 7b,c). LAG 1 radius measurements for captive and wild sea turtles were not significantly different (MannWhitney $U$-test, $0.10>\mathrm{p}>0.05, \mathrm{n}=3$ known-age, $\mathrm{n}=$ 11 wild). However, captive LAG 1 radius measurements occurred at the larger end of the size distribution, perhaps reflecting the captive sea turtles' probable larger size relative to wild juveniles of the same age. Early LAGs following LAG 1 in the wild ossicles
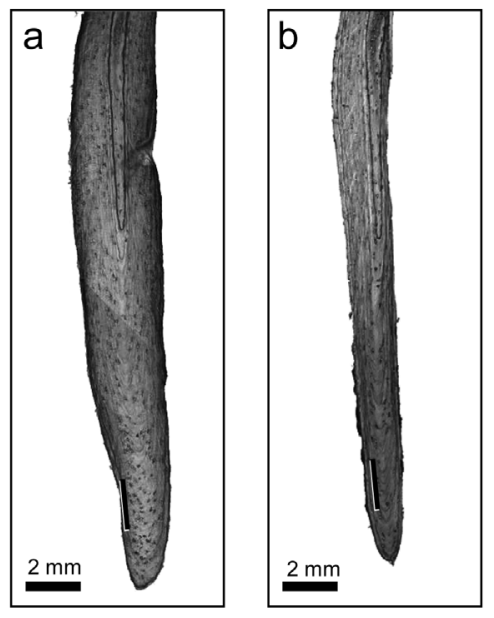

Fig. 7. Dermochelys coriacea. Wide ossicle tips for (a) a captive-reared leatherback, $24.9 \mathrm{~cm}$ straight carapace length (SCL), and $1.28 \mathrm{yr}$ old, (b) a wild leatherback, $27.3 \mathrm{~cm}$ curved carapace length (CCL), stranded 28 Feb 2006, estimated age $1+\mathrm{yr}$, and (c) a wild leatherback, $133.4 \mathrm{~cm} \mathrm{CCL}$, estimated age $24 \mathrm{yr}$. Dark lines denote location of Year 1 growth mark in $(\mathrm{a}-\mathrm{c})$ and dashed lines in (c) indicate 3 subsequent marks interpreted as annual

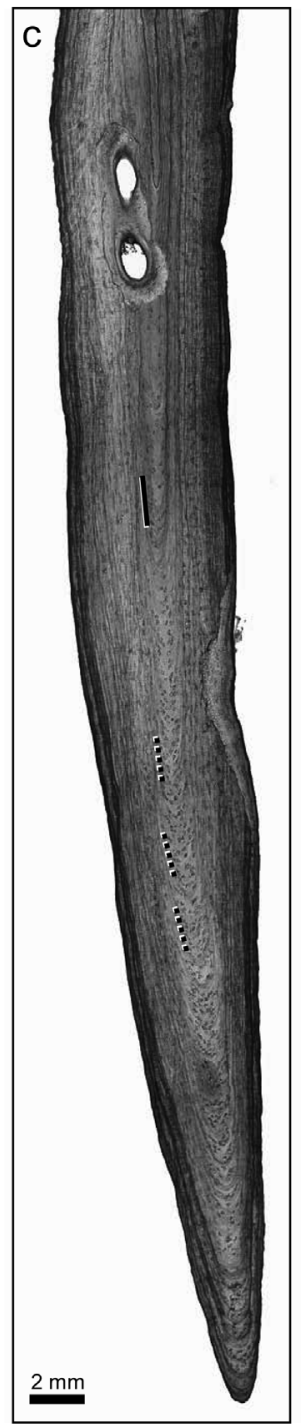




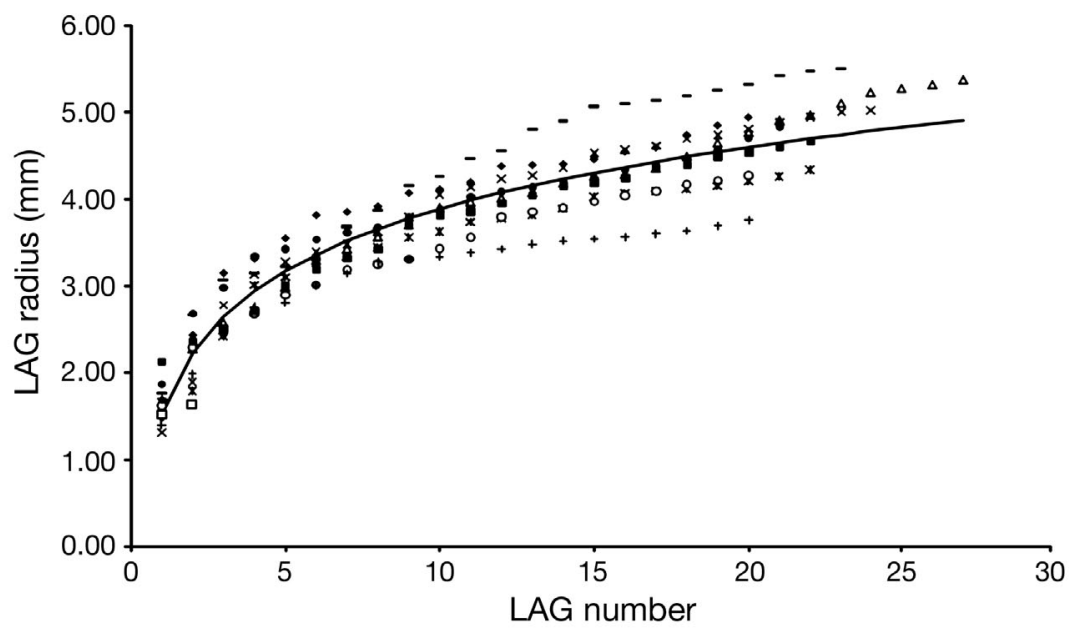

Fig. 8. Dermochelys coriacea. Plot of line of arrested growth (LAG) number versus LAG radius $(n=202)$ for 11 leatherbacks whose ossicles exhibited little to no resorption and in which the earliest growth marks (beginning with LAG 1) were visible. Different symbols represent individual ossicle growth trajectories for different individuals. The relationship between LAG number and LAG radius for the grouped data was best described by the logarithmic equation $y=1.028 \ln (x)+1.5167\left(R^{2}=0.862\right)$

were similar in appearance, lending confidence to their interpretation as annual marks (Fig. 7c).

The relationship between LAG number and LAG radius within wild leatherback ossicles was described by a logarithmic curve (Fig. 8). Resorption core radius was substituted for LAG radius within the equation to yield an estimate of the number of resorbed LAGs, which was then added to the observed number of LAGs to yield an age estimate for each sea turtle.

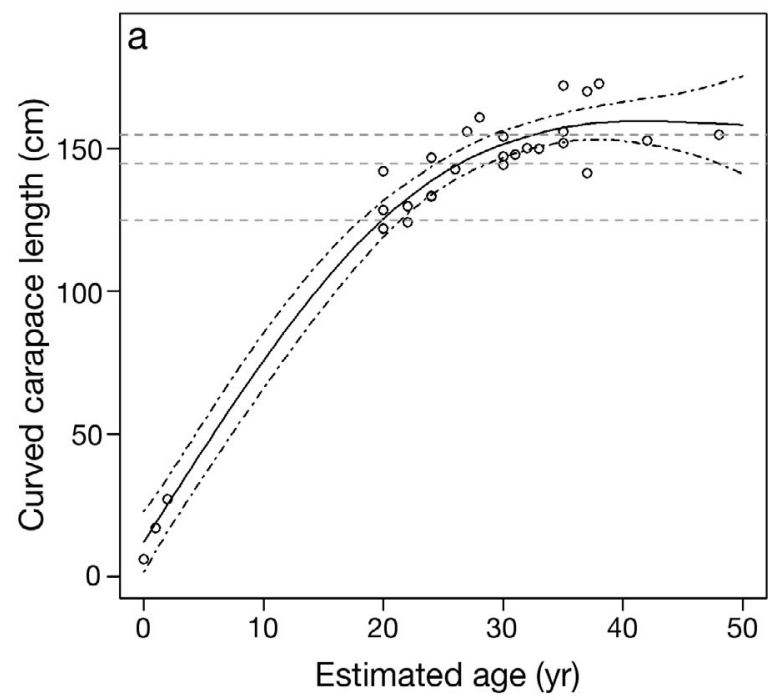

The general shapes of the smoothing spline and von Bertalanffy growth functions were nearly identical (Fig. 9). Parameter estimates for the von Bertalanffy growth models were similar between the delta method and bootstrap uncertainty analysis (estimate 95\% CI): $L_{\infty}=169.2$ (158.65 to 185.6$), k=0.07$ $(0.05$ to 0.09$), t_{0}=-0.46 \quad(-0.70$ to $-0.30)$. Although it is not common, females as small as $125 \mathrm{~cm}$ CCL are occasionally observed on nesting beaches. The $95 \%$ confidence regions for the smoothing spline model predicted that turtles of this size are 18 to $22 \mathrm{yr}$ of age (Fig. 9a), while the von Bertalanffy curve estimates ranged from 16 to 20.5 yr (Fig. 9b). Age estimates for sea turtles $145 \mathrm{~cm}$ in CCL, a more typical size for first-time nesters, ranged from 24.5 to $29 \mathrm{yr}$ of age for both models (Fig. 9a,b). Finally, the smoothing spline and von Bertalanffy curve predicted that average-sized nesting sea turtles $155 \mathrm{~cm}$ in CCL may be $>29$ or 31 to $43 \mathrm{yr}$ old, respectively (Fig. 9a,b). The age-specific maturation function performed poorly for 125 and $155 \mathrm{~cm}$ CCL where sample sizes were low. For $145 \mathrm{~cm} \mathrm{CCL}$, the model predicted that median age at maturation would be $27 \mathrm{yr}(95 \% \mathrm{CI}=$

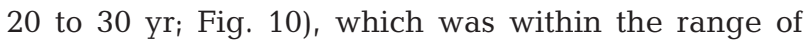
estimates predicted by the smoothing spline model and the von Bertalanffy curve.

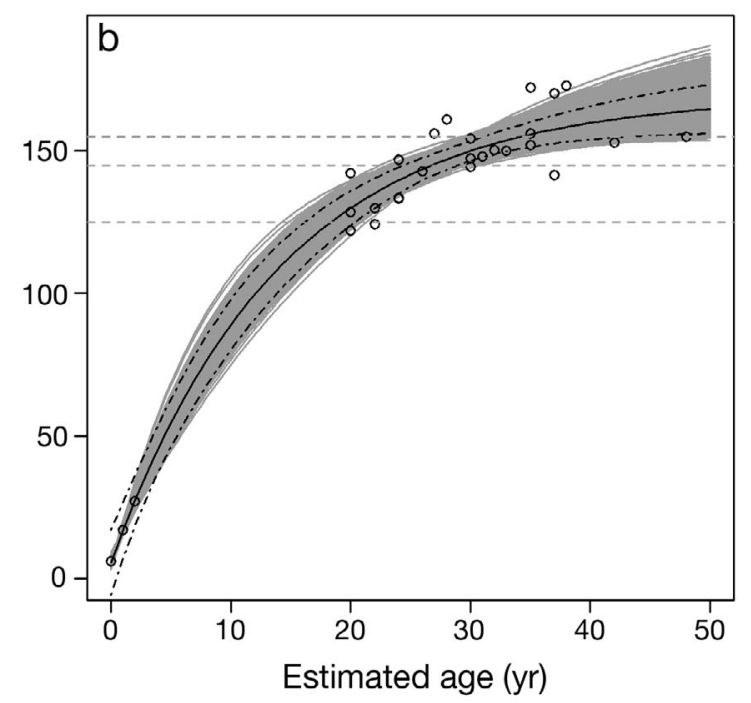

Fig. 9. Dermochelys coriacea. (a) Smoothing spline and (b) von Bertalanffy growth curve fit to age estimate and curved carapace length (CCL) data. Dashed lines following the curves denote $95 \%$ credible intervals. Horizontal dashed lines correspond to 125 , 145, and $155 \mathrm{~cm} \mathrm{CCL}$, respectively. Size at estimated age data are shown as open circles. Gray shading in (b) shows results from 10000 bootstrap permutations of the size at estimated age data 


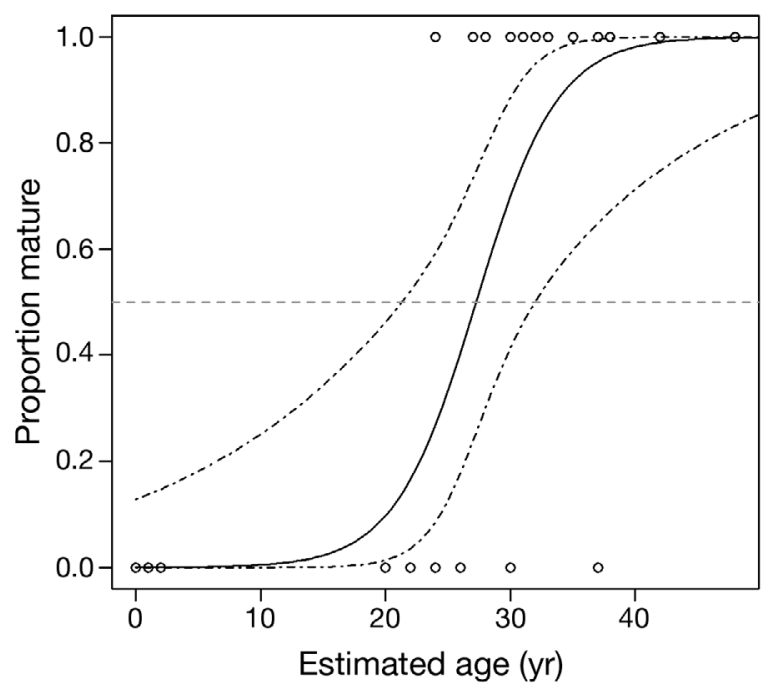

Fig. 10. Dermochelys coriacea. Plot of size-at-age function fitted assuming size at first nesting of $145 \mathrm{~cm}$. The model was fit to the data using a generalized smoothing spline (solid line). Size at estimated age data are shown as open circles. Dashed lines following the curve denote $95 \%$ credible intervals. Horizontal dashed line corresponds to 0.50 proportion mature

\section{DISCUSSION}

The analyses presented here indicate that median age at maturation for leatherbacks in the western North Atlantic Ocean ranges from 24.5 to 29 yr (Figs. 9 $\& 10)$. These ages are far greater than the early estimates of 2 to $6 \mathrm{yr}$ (Deraniyagala 1952, Birkenmeier 1971, Rhodin 1985, Bels et al. 1988). However, the lower end of our predicted 16 to $22 \mathrm{yr}$ age range for $125 \mathrm{~cm}$ CCL sea turtles does approach the span of 12 to $18 \mathrm{yr}$ that encompasses more recent results from skeletochronology, genetic analyses, and captive rearing (Zug \& Parham 1996, Dutton et al. 2005, Jones 2009). Sex-specific differences in growth and maturation have been demonstrated for other marine turtle species, with males tending toward faster growth rates and earlier maturation (Chaloupka \& Limpus 1997, Limpus \& Chaloupka 1997, Snover 2002). Given that our sample of large juveniles and adults included both males and females, if a similar dichotomy in growth patterns exists for leatherbacks, this would negatively bias our age estimates for nesting females.

\section{Growth mark interpretation}

As with all skeletochronology studies, the estimates of age at maturation presented herein are dependent upon interpretation of the growth marks within the scleral ossicles. Accurate reads are of course essential, as errors in interpretation can confound age estimates and resulting interpretation of individual and population vital rates (Ardizzone et al. 2006).

Prior to conducting age analyses using hard structures, it is necessary to determine the most appropriate axis along which to conduct growth-mark counts (Lagardère et al. 1995). Zug \& Parham (1996) described and analyzed marks visible at the lateral edges of leatherback ossicle sections. However, as predicted from a recent analysis of cheloniid turtle ossicles (Avens \& Goshe 2007), mark clarity and spacing was better at the wide tips of leatherback ossicle sections due to lateral mark compression and relatively greater resorption at ossicle centers (Fig. 2). As a result, this was the axis along which we obtained our LAG counts and we recommend that future analyses also focus on this region.

Despite the confidence in the location of the growth mark counts, some uncertainty regarding the frequency of mark deposition in the ossicles remains. Growth-mark deposition has been most strongly linked to variations in ectotherm growth rates that are caused by seasonal temperature fluctuations (e.g. Hutton 1986). However, leatherbacks are atypical for reptiles in that they are able to maintain their body temperature well above ambient (James et al. 2006). In theory, the elevated body temperature and high vascularization of leatherback skeletal elements might allow more or less continuous growth, as is the case for most birds (Turvey et al. 2005), with mark deposition resulting from other factors influencing growth rates. However, hard structures in mammals (reviewed by Klevezal 1996) and tropical reptiles and amphibians (Zug \& Rand 1987, Chinsamy et al. 1995, Kusrini \& Alford 2006) experiencing less annual thermal variability than the leatherback have been found to contain annual growth marks. Furthermore, controlled laboratory experiments have not revealed a positive relationship between degree of vascularization and growth rates in bird bones (Starck \& Chinsamy 2002). Growth mark deposition appears to be predominantly driven by endogenous cycles that function even in the absence of environmental influence (Schauble 1972, Simmons 1992). As a result, it would be expected that the hard structures of leatherbacks, like most other non-avian vertebrates studied to date (Castanet et al. 1993, Secor et al. 1995, Klevezal 1996), would also exhibit annual cycles of deposition. This supposition is supported by the observation that annual growth marks were observed in the captive leatherbacks $>1 \mathrm{yr}$ old, although they had been reared under fairly constant environmental conditions (Jones 2009).

Another issue is the interpretation of the light and dark marks within the ossicles. Aside from the influence of endogenous factors on growth mark deposi- 
tion, this process can also be affected by physiological and environmental stressors; aestivation, disease, food shortage, and adverse climatic conditions may all alter somatic growth and yield mark formation (Klevezal 1996, Sinsch et al. 2007). Furthermore, long and energetically expensive migrations, such as those exhibited by Atlantic tuna species, have been linked to mark deposition (Compeán-Jimenez \& Bard 1983). In many other cases, although the factors underlying deposition are not necessarily well understood, annual cycles are also represented by more than one mark (e.g. salamanders, Castanet et al. 1993; cetaceans [growth layer groups], reviewed by Hohn 2002; terrestrial mammals, Klevezal 1996; chondrichthyans [band pairs], Cailliet et al. 2006; fish otoliths, Casselman 1983).

In the North Atlantic, leatherbacks undertake seasonal migrations that span the ocean basin (Hays et al. 2004, Eckert 2006) and their behavior suggests that foraging may occur to some extent during these movements (Hays et al. 2006). However, if the energetic requirements of continuous, high-speed swimming and diving exceed the level of prey intake during travel, this could result in cessation of somatic growth and mark deposition within the bones during migration. The leatherback's spring/early summer migration to northern foraging areas (periodically after directing considerable resources toward reproduction) might correspond with deposition of the annual, dark LAG, while the lighter marks within the groups could relate to additional migrations undertaken by these sea turtles each year. In light of these precedents, we counted each group of LAGs in leatherback scleral ossicles as a single, annual growth mark, presuming that the darker, more distinct mark demarcated the annual cycle and was deposited in winter/spring (Klevezal 1996), as found for cheloniid sea turtles (Snover \& Hohn 2004).

Recent isotopic analyses have begun to investigate potential differences in the microchemistry of the light and dark LAGs, which could provide information about the timing of mark deposition (R. Day unpubl. data). However, additional work is needed to address the frequency of deposition, possibly through bonemarking studies (reviews in Frazier 1985, Klevezal 1996) or bomb radiocarbon analysis (e.g. Campana 1997, Ardizzone et al. 2006).

\section{Delayed maturation and life-history considerations}

Although our proposed age at maturation estimate of 24.5 to $29 \mathrm{yr}$ for leatherbacks contrasts sharply with earlier estimates of 2 to 6 yr (Deraniyagala 1952, Birkenmeier 1971, Rhodin 1985, Bels et al. 1988), our results do approach the 30 to $40 \mathrm{yr}$ range established for the larger, cheloniid sea turtle species (Limpus 1979, NMFS SEFSC 2001, Snover 2002, Zug et al. 2002, Heppell et al. 2003b, Balazs \& Chaloupka 2004). It may seem difficult at first to draw direct parallels between leatherback life history and that of cheloniid sea turtles because the lineages diverged at least 100 million years ago (Bowen \& Karl 2007). Furthermore, leatherbacks display some unusual characteristics, such as their enormous size as adults, and their lack of a true carapace (Eckert \& Luginbuhl 1988, Stewart et al. 2007). Also unlike cheloniid sea turtles, leatherbacks are able to maintain their body temperatures well above that of their surroundings, allowing them to forage at high latitudes (Spotila et al. 1997, James et al. 2006). In the course of their movements between these feeding areas and tropical breeding sites, leatherbacks transit over exceptionally long distances (Eckert 2006, Hays et al. 2006). Finally, for all their large size and presumed metabolic requirements, leatherbacks subsist almost solely on an 'energetically improbable' diet of gelatinous prey (Houghton et al. 2006).

Despite these singular qualities, many fundamental similarities exist between leatherbacks and their closest extant relatives. Resting metabolic rates of leatherbacks do not differ from those of green sea turtles (or other reptiles); their elevated body temperature results instead from anatomical adaptations that very effectively retain behaviorally generated heat (Wallace \& Jones 2008). In addition, leatherbacks display an iteroparous reproductive strategy similar to that of cheloniid sea turtles, in which females lay 2 to 10 nests each reproductively active year at intervals of 2 to $5 \mathrm{yr}$ (van Buskirk \& Crowder 1994). Nesting occurs on oceanic beaches and, as for all other marine turtle species, stochastic environmental conditions combined with predation can yield low nest and/or hatchling survival (Frazer 1987, Leslie et al. 1996). Once in the water, hatchling leatherback and cheloniid turtles alike are vulnerable to predators, and survival rates can be low (Gyuris 1994, Spotila et al. 1996, TEWG 2007, but see Stewart \& Wyneken 2004). By contrast, large juvenile and adult survival probabilities are estimated to be relatively high (Frazer 1986, 1987, Troëng et al. 2007, TEWG 2007).

Given this extensive concurrence, it is possible that the selective pressures leading to the life-history characteristics described above, including delayed maturation, may have acted similarly for all marine turtle species. Growing to and maintaining a large size is energetically expensive and only worthwhile if this increased size also yields a corresponding increase in reproductive success (Gadgil \& Bossert 1970, Stearns 1992, Charnov et al. 2001). Total egg output does increase with body size for green (Broderick et al. 2003) and leatherback (Price et al. 2006) sea turtles, 
indicating that such a benefit may exist. Large adult size can confer a size refuge from predation (Takada \& Caswell 1997), yielding increased adult survival rates, which in turn have been found to correlate positively with age at maturation (e.g. for squamate reptiles, Shine \& Charnov 1992). Low juvenile survival can result in selection against reproductive effort at smaller sizes and/or younger ages (Law 1979, Michod 1979, Reznick et al. 2002) so that all available energy is devoted to growth during this time, to move beyond the vulnerable stage(s) (Takada \& Caswell 1997). The effects of stochastic environmental conditions on reproductive success are thought to select for bet-hedging, where organisms are long-lived to distribute reproductive effort over space and time, maximizing the probability of offspring survival over the course of the reproducer's life span (Stearns 1992, Sæther et al. 1996). Finally, the trait of delayed age to maturity in sea turtles might simply be phylogenetically constrained (Stearns 1984, 1992, Dunham \& Miles 1985), as is thought to be the case for their metabolic rates (Wallace \& Jones 2008).

It should be noted, however, that despite the convergence of delayed age at maturation estimates among the larger sea turtle species, the growth rates of leatherbacks remain accelerated relative to those of cheloniid turtles (Snover \& Rhodin 2008). Although Atlantic leatherback hatchlings are only slightly larger than those of loggerhead or green sea turtles, the mean carapace length of nesting female leatherbacks exceeds that of the other 2 species by approximately $50 \%$ (Buskirk \& Crowder 1994, Stewart et al. 2007). As a result, it appears that leatherbacks are still conferred some advantage by reaching large size more quickly, perhaps related to the thermoregulatory capacity that allows them to exploit a foraging niche not available to other sea turtle species.

\section{Implications for conservation}

Accurate information relating age to reproductive effort is essential to understanding population dynamics and assessing the effectiveness of potential management strategies (Sæther et al. 1996, Chaloupka \& Musick 1997, Heppell et al. 2003a). When age at maturation is underestimated, as has occurred on a number of occasions for various fish species, this can introduce inaccurate assumptions regarding population resilience to negative impacts, which in turn can have disastrous management implications (see Summerfelt \& Hall 1987, Secor et al. 1995, Cailliet et al. 2006 for reviews).

The age at maturation estimates presented here for leatherbacks may seem unexpectedly high relative to earlier published values (Deraniyagala 1952, Birkenmeier 1971, Rhodin 1985, Bels et al. 1988, Zug \& Parham 1996, Dutton et al. 2005). However, the tendency toward increasing estimates of age at maturation as the techniques used to study age and growth are refined over time is consistent with the pattern seen for hard-shelled marine turtle age estimates over the past several decades (Caldwell 1962, Uchida 1967, Hirth 1971, Limpus 1979, Mendonça 1981, NMFS SEFSC 2001, Snover 2002, Zug et al. 2002, Heppell et al. 2003b, Balazs \& Chaloupka 2004). Discrepancies among results from the various leatherback age studies are likely due to a number of factors. Early studies of captive leatherback hatchlings reared in constant conditions and fed unusual diets yielded rapid growth rates not necessarily representative of wild individuals, and analyses of these data did not always take into account growth rate decay through ontogenetic stages (Deraniyagala 1952, Birkenmeier 1971, Bels et al. 1988). The results of our skeletochronological analysis of leatherback ossicles indicate that growth mark compaction and resorption may have resulted in a lower estimate of age at maturation for an earlier Pacific leatherback skeletochronology study (Zug \& Parham 1996), although population-specific differences in age and growth are possible. Finally, although DNA fingerprinting data for a Caribbean nesting population provide compelling evidence for a minimum reproductive age of 12 to $14 \mathrm{yr}$, the mixture of possible motherdaughter and sister-sister relationships can confound interpretation of lineages (Dutton et al. 2005).

Leatherbacks are listed as Critically Endangered worldwide (IUCN 2006), with nesting populations in the Pacific having undergone catastrophic collapse in the past few decades (Chan \& Liew 1996, Spotila et al. 1996, 2000, Hitipeuw et al. 2007, Sarti Martínez et al. 2007). By contrast, some western North Atlantic nesting populations are increasing dramatically, while others remain stable (TEWG 2007), or are perhaps even decreasing (Troëng et al. 2007). The increasing trends are encouraging and in some cases have been attributed to recently implemented protective measures taking effect over the presumed short generation time of the leatherback (Dutton et al. 2005). However, some conservation efforts that have been in place for 15 to $20 \mathrm{yr}$ in the Pacific have yet to yield an increase in nesting populations (Huppert \& Mittleman 1993, Hitipeuw et al. 2007, Sarti Martínez et al. 2007). Although this lack of recovery might be due to continued low survival rates, it is also possible that sufficient time has not passed for the hatchlings and juveniles impacted by these recovery efforts to have matured and returned to nest.

Despite some uncertainty associated with the estimates of age at maturation proposed here, they might 
serve as a caution for researchers and managers, as they carry with them potentially significant implications for the future of this species. Leatherbacks face many threats to their survival, including habitat degradation and destruction, directed take, and fisheries bycatch (TEWG 2007). Therefore, if these turtles do require decades to reach maturity, then the ability of populations to recover from such negative impacts is going to be diminished relative to current expectations.

Acknowledgements. We are extremely grateful for the sample collection conducted by participants in the national Sea Turtle Stranding and Salvage Network; without their assistance this work would not have been possible. Special thanks go to R. Bailey, M. Baker, S. Barco, S. Barris, L. Belskis, B. Biehl, R. Boettcher, D. Burnsed, W. Cluse, J. Cordes, M. Dodd, K. Dodge, B. Dunnigan, S. Epperly, N. Evou, N. Fahey, M. Godfrey, T. Hanson, B. Higgins, C. Huston, S. Johnson, S. Kethan, R. Leonard, A. Marcie, A. McKinnon, C. Merigo, N. Mihnovets, S. Mills, T. Murphy, L. Nester, L. Purcell, M. Rikard, E. Seney, S. Sinclaire, J. Snukis, W. Teas, M. Tierney, C. Trapani, and J. Wyneken. The research and manuscript were improved through discussions with and comments from J. Braun-McNeill, A. Chester, S. Epperly, M. Fonseca, E. Griffith, L. Hansen, A. Hohn, P. Marraro, M. Snover, G. Zug, and anonymous reviewers. Skeletochronology was conducted under NMFS Scientific Research permit no. 1260 and USFWS permit no. TE-676379-2 issued to the NMFS SEFSC. Captive leatherback turtles were obtained on Canada CITES import permit CA05CWIM0039 and British Virgin Islands CITES export certificate CFD62005. The turtles were housed and maintained for research purposes, and all animal care standards of the Canadian Council for Animal Care and the UBC Animal Care Committee were met (UBC Animal Care Protocol: A04-0323). Samples from captive turtles were transferred to the USA under CITES permit 05US844694/9. The captive rearing program was supported by an NSERC Discovery grant to D. R. Jones.

\section{LITERATURE CITED}

Ardizzone D, Cailliet GM, Natanson LJ, Andrews AH, Kerr LA, Brown TA (2006) Application of bomb radiocarbon chronologies to shortfin mako (Isurus oxyrinchus) age validation. Environ Biol Fishes 77:355-366

Avens L, Goshe LR (2007) Comparative skeletochronological analysis of Kemp's ridley (Lepidochelys kempii) and loggerhead (Caretta caretta) humeri and scleral ossicles. Mar Biol 152:1309-1317

Balazs GH, Chaloupka M (2004) Spatial and temporal variability in somatic growth of green sea turtles (Chelonia mydas) resident in the Hawaiian Archipelago. Mar Biol 145:1043-1059

Beamish RJ, Fournier DA (1981) A method for comparing the precision of a set of age determinations. Can J Fish Aquat Sci 38:982-983

Bels B, Rimbolt-Baly F, Lescure J (1988) Croissance et maintien en captivité, de la tortue luth Dermochelys coriacea (Vandelli, 1761). Rev Fr Aquariol 15:59-64

Birkenmeier E (1971) Juvenile leathery turtles, Dermochelys coriacea (Linnaeus), in captivity. Brunei Mus J 2:160-172
Bishop SDH, Francis MP, Duffy C, Montgomery JC (2006) Age, growth, maturity, longevity, and natural mortality of the shortfin mako shark (Isurus oxyrinchus) in New Zealand waters. Mar Freshw Res 57:143-154

Bjorndal KA, Bolten AB, Dellinger T, Delgado C, Martins HR (2003) Compensatory growth in oceanic loggerhead sea turtles: response to a stochastic environment. Ecology 84:1237-1249

Bowen BW, Karl SA (2007) Population genetics and phylogeography of sea turtles. Mol Ecol 16:4886-4907

Braun-McNeill J, Epperly SE, Avens L, Snover ML, Taylor JC (2008) Growth rates of loggerhead (Caretta caretta) sea turtles from the western North Atlantic. Herpetol Conserv Biol 3:273-281

Broderick AC, Glen F, Godley BJ, Hays GC (2003) Variation in reproductive output of marine turtles. J Exp Mar Biol Ecol 288:95-109

Cailliet GM, Smith WD, Mollet HF, Goldman KJ (2006) Age and growth studies of chondrichthyan fishes: the need for consistency in terminology, verification, validation, and growth function fitting. Environ Biol Fishes 77:211-228

Caldwell D (1962) Growth measurements in young captive Atlantic sea turtles in temperate waters. Los Angel City Mus Contrib Sci 50:1-8

Campana SE (1997) Use of radiocarbon from nuclear fallout as a dated marker in the otoliths of haddock Melanogrammus aeglefinus. Mar Ecol Prog Ser 150:49-56

Carr A (1967) So excellent a fishe: a natural history of sea turtles. The Natural History Press, New York

Casselman JM (1983) Age and growth assessment of fish from their calcified structures: techniques and tools. NOAA Tech Rep NMFS 8:1-17

Castanet J, Francillon-Viellot H, Meunier FJ, DeRicqles A (1993) Bone and individual aging. In: Hall BK (ed) Bone. Vol 7: bone growth-B. CRC Press, Boca Raton, FL, p 245-283

Chaloupka MY, Limpus CJ (1997) Robust statistical modeling of hawksbill sea turtle growth rates (southern Great Barrier Reef). Mar Ecol Prog Ser 146:1-8

Chaloupka MY, Musick JA (1997) Age, growth, and population dynamics. In: Lutz P, Musick J (eds) The biology of sea turtles. CRC Press, Boca Raton, FL, p 233-276

Chan EH, Liew HC (1996) Decline of the leatherback population in Terengganu, Malaysia, 1956-1995. Chelonian Conserv Biol 2:196-203

> Charnov EL, Turner TF, Winemiller KO (2001) Reproductive constraints and the evolution of life histories with indeterminate growth. Proc Natl Acad Sci USA 98:9460-9464

Chinsamy A, Hanrahan SA, Neto RM, Seely M (1995) Skeletochronological assessment of age in Angolosaurus skoogi, a cordylid lizard living in an aseasonal environment. J Herpetol 29:457-460

Compeán-Jimenez G, Bard FX (1983) Growth increments on dorsal spines of eastern Atlantic bluefin tuna, Thunnus thynnus, and their possible relation to migration patterns. In: Prince ED, Pulos LM (eds) Proceedings of the international workshop on age determination of oceanic pelagic fishes: tunas, billfishes, and sharks. NOAA Tech Rep NMFS 8:77-86

Deraniyagala PEP (1952) A colored atlas of some vertebrates from Ceylon. Vol I (Fishes). The Ceylon Government Press, Colombo, p 3-21

Dunham AE, Miles DB (1985) Patterns of covariation in life history traits of squamate reptiles: the effects of size and phylogeny reconsidered. Am Nat 126:231-257

Dutton DL, Dutton PH, Chaloupka M, Boulon RH (2005) Increase of a Caribbean leatherback turtle Dermochelys 
coriacea nesting population linked to long-term nest protection. Biol Conserv 126:186-194

Eckert SA (2006) High-use oceanic areas for Atlantic leatherback sea turtles. Mar Biol 149:1257-1267

Eckert KL, Luginbuhl C (1988) Death of a giant. Mar Turtle Newsl 43:2-3

Frazer NB (1986) Survivorship of adult female loggerhead sea turtles, Caretta caretta, nesting on Little Cumberland Island, Georgia, USA. Herpetologica 39:436-447

Frazer NB (1987) Preliminary estimates of survivorship for wild juvenile loggerhead sea turtles (Caretta caretta). J Herpetol 21:232-235

Frazer NB, Ehrhart LM (1985) Preliminary growth models for green, Chelonia mydas, and loggerhead, Caretta caretta, turtles in the wild. Copeia 1985:73-79

Frazer NB, Schwartz F (1984) Growth curves of captive loggerhead turtles, Caretta caretta, in North Carolina, USA. Bull Mar Sci 34:485-489

Frazier J (1985) A review of in vivo labels for studies of age determination and growth in amphibians and reptiles. Herpetologica 41:222-227

Gadgil M, Bossert WH (1970) Life historical consequences of natural selection. Am Nat 104:1-24

Gyuris E (1994) The rate of predation by fishes on hatchlings of the green turtle (Chelonia mydas). Coral Reefs 13: 137-144

Hays GC, Houghton JDR, Myers AE (2004) Endangered species: pan-Atlantic leatherback turtle movements. Nature 429:522

Hays GC, Hobson VJ, Metcalfe JD, Righton D, Sims DW (2006) Flexible foraging movements of leatherback turtles across the north Atlantic Ocean. Ecology 87:2647-2656

Heppell SS, Snover ML, Crowder LB (2003a) Sea turtle population ecology. In: Lutz PL, Musick JA, Wyneken J (eds) The biology of sea turtles, Vol II. CRC Press, Boca Raton, FL, p 275-306

Heppell SS, Crowder LB, Crouse DT, Epperly SP, Fraser NB (2003b) Population models for Atlantic loggerheads: past, present, and future. In: Bolten $\mathrm{AB}$, Witherington $\mathrm{BE}$ (eds) Loggerhead sea turtles. Smithsonian Books, Washington, DC, p 255-273

Hirth HF (1971) Synopsis of biological data on the green turtle, Chelonia mydas (Linnaeus) 1758. Food and Agriculture Organization of the United Nations, Rome

Hitipeuw C, Dutton PH, Benson S, Thebu J, Bakarbessy J (2007) Population status and internesting movement of leatherback turtles, Dermochelys coriacea, nesting on the northwest coast of Papua, Indonesia. Chelonian Conserv Biol 6:28-36

Hohn AA (2002) Age estimation. In: Perrin WF, Wursig B, Thewissen HGM (eds) Encyclopedia of marine mammals. Academic Press, London, p 6-13

> Houghton JDR, Doyle TK, Wilson MW, Davenport J, Hays GC (2006) Jellyfish aggregations and leatherback turtle foraging patterns in a temperate coastal environment. Ecology 87:1967-1972

Huppert DD, Mittleman TW (1993) Economic effects of the United Nations moratorium on high seas driftnet fishing. NOAA Tech Memo NMFS-SWFSC-194

Hutton JM (1986) Age determination of living Nile crocodiles from the cortical stratification of bone. Copeia 1986: 332-341

IUCN (International Union for the Conservation of Nature and Natural Resources) (2008) IUCN Red List of Threatened Species. Available at: www.iucnredlist.org/

> James JC, Davenport J, Hays GC (2006) Expanded thermal niche for a diving vertebrate: a leatherback turtle diving into near-freezing water. J Exp Mar Biol Ecol 335:221-226
Jones TT (2009) Energetics of the leatherback turtle, Dermochelys coriacea. PhD dissertation, University of British Columbia, Vancouver, BC

Klevezal GA (1996) Recording structures of mammals: determination of age and reconstruction of life history. A. A. Balkema, Brookfield, VT

Klinger RC, Musick JA (1995) Age and growth of loggerhead turtles Caretta caretta from Chesapeake Bay. Copeia 1995:204-209

Kusrini MD, Alford RA (2006) The application of skeletochronology to estimate ages of three species of frogs in West Java, Indonesia. Herpetol Rev 37:423-425

Lagardère F, Chaumillon G, Amara R, Heineman G, Lago JM (1995) Examination of otolith morphology and microstructure using laser scanning microscopy. In: Secor DH, Dean JM, Camapana SE (eds) Recent developments in fish otolith research. University of South Carolina Press, Columbia, SC

> Law R (1979) Optimal life histories under age-specific predation. Am Nat 114:399-417

Leslie AJ, Penick DN, Spotila JR, Paladino FV (1996) Leatherback turtle, Dermochelys coriacea, nesting and nest success at Tortuguero, Costa Rica, in 1990-1991. Chelonian Conserv Biol 2:159-168

Limpus C (1979) Notes on growth rates of wild turtles. Mar Turtle Newsl 10:3-5

Limpus C, Chaloupka M (1997) Nonparametric regression modeling of green sea turtle growth rates (southern Great Barrier Reef). Mar Ecol Prog Ser 149:23-34

Limpus CJ, Walter DG (1980) The growth of immature green turtles (Chelonia mydas) under natural conditions. Herpetologica 36:162-165

> Mendonça MT (1981) Comparative growth rates of wild immature Chelonia mydas and Caretta caretta in Florida. J Herpetol 15:447-451

Michod RE (1979) Evolution of life histories in response to age-specific mortality factors. Am Nat 113:531-550

Myrick MC, Hohn AA, Sloan PA, Kimura M, Stanely DD (1983) Estimating age of spotted and spinner dolphins (Stenella attenuate and Stenella longirostris) from teeth. NOAA Tech Memo NMFS-SWFSC-30

NMFS SEFSC (National Marine Fisheries Service Southeast Fisheries Science Center) (2001) Stock assessments of loggerhead and leatherback sea turtles and an assessment of the impact of the pelagic longline fishery on the loggerhead and leatherback sea turtles of the Western North Atlantic. NOAA Tech Memo NMFS-SEFSC-455

Parham JF, Zug GR (1997) Age and growth of loggerhead sea turtles Caretta caretta of coastal Georgia: an assessment of skeletochronological age-estimates. Bull Mar Sci 61: 287-304

Price ER, Wallace BP, Reina RD, Spotila JR, Paladino FV, Piedra R, Vélez E (2006) Size, growth, and reproductive output of adult female leatherback turtles Dermochelys coriacea. Endang Species Res 1:41-48

Reznick D, Bryant MJ, Bashey F (2002) $r$ - and $K$-selection revisited: the role of population regulation in life-history evolution. Ecology 83:1509-1520

Rhodin AGJ (1985) Comparative chondro-osseous development and growth of marine turtles. Copeia 1985:752-771

Sæether BE, Ringsby TH, Røskaft E (1996) Life history variation, population processes and priorities in species conservation: towards a reunion of research paradigms. Oikos $77: 217-226$

> Sarti Martínez L, Barragán AR, Muñoz DG, García N, Huerta P, Vargas F (2007) Conservation and biology of the leatherback turtle in the Mexican Pacific. Chelonian Conserv Biol 6:70-78 
Schauble MK (1972) Seasonal variation of newt forelimb regeneration under controlled environmental conditions. J Exp Zool 181:281-286

Secor DH, Dean JM, Campana SE (1995) Recent developments in fish otolith research. University of South Carolina Press, Columbia, SC

Shine R, Charnov EL (1992) Patterns of survival, growth, and maturation in snakes and lizards. Am Nat 139:1257-1269

Simmons DJ (1992) Circadian aspects of bone biology. In: Hall BK (ed) Bone. Vol 6: bone growth-A. CRC Press, Boca Raton, FL, p 91-128

Sinsch U, Oromi N, Sanuy D (2007) Growth marks in the natterjack toad (Bufo calamita) bones: histological correlates of hibernation and aestivation periods. Herpetol J 17:129-137

Snover ML (2002) Growth and ontogeny of sea turtles using skeletochronology: methods, validation, and application to conservation. PhD dissertation, Duke University, Durham, NC

Snover ML, Hohn AA (2004) Validation and interpretation of annual skeletal marks in loggerhead (Caretta caretta) and Kemp's ridley (Lepidochelys kempii) sea turtles. Fish Bull 102:682-692

Snover ML, Rhodin AGJ (2008) Comparative ontogenetic and phylogenetic aspects of chelonian chondro-osseous growth and skeletochronology. In: Wyneken J, Godfrey $\mathrm{MH}$, Bels V (eds) Biology of turtles. CRC Press, Boca Raton, FL, p 17-43

Spotila JR, Reina RD, Steyermark AC, Plotkin PT, Paladino FV (1996) Worldwide population decline of Dermochelys coriacea: Are leatherback turtles going extinct? Chelonian Conserv Biol 2:209-222

Spotila JR, O'Connor MP, Paladino FV (1997) Thermal biology. In: Lutz P, Musick J (eds) The biology of sea turtles. CRC Press, Boca Raton, FL, p 297-314

Spotila JR, Reina RD, Steyermark AC, Plotkin PT, Paladino FV (2000) Pacific leatherback turtles face extinction. Nature 405:529-530

Starck JM, Chinsamy A (2002) Bone microstructure and developmental plasticity in birds and other dinosaurs. J Morphol 254:232-246

Stearns SC (1984) The effects of size and phylogeny on patterns of covariation in the life history traits of lizards and snakes. Am Nat 123:56-72

Stearns SC (1992) The evolution of life histories. Oxford University Press, Oxford

Stewart KR, Wyneken J (2004) Predation risk to loggerhead hatchlings at a high-density nesting beach in southeast Florida. Bull Mar Sci 74:325-335

Stewart K, Johnson C, Godfrey MH (2007) The minimum size of leatherbacks at reproductive maturity, with a review of sizes for nesting females from the Indian, Atlantic, and Pacific Ocean basins. Herpetol J 17:123-128

Editorial responsibility: Matthew Godfrey, Beaufort, North Carolina, USA
Summerfelt RC, Hall GE (1987) Age and growth of fish. Iowa State University Press, Ames, IA

Takada T, Caswell H (1997) Optimal size at maturity in sizestructured populations. J Theor Biol 187:81-93

TEWG (Turtle Expert Working Group) (2007) An assessment of the leatherback turtle population in the Atlantic Ocean. NOAA Tech Memo NMFS-SEFSC-555

Troëng S, Harrison E, Evans D, de Haro A, Vargas E (2007) Leatherback turtle nesting trends and threats at Tortuguero, Costa Rica. Chelonian Conserv Biol 6:117-122

> Turvey ST, Green OR, Holdaway RN (2005) Cortical growth marks reveal extended juvenile development in $\mathrm{New}$ Zealand moa. Nature 435:940-943

Uchida I (1967) On the growth of the loggerhead turtle, Caretta caretta, under rearing conditions. Bull Jpn Soc Sci Fish 33:497-506

van Buskirk J, Crowder LB (1994) Life-history variation in marine turtles. Copeia 1994:66-81

von Bertalanffy L (1938) A quantitative theory of organic growth (inquiries on growth laws. II). Hum Biol 10:181-213

Wallace BP, Jones TT (2008) What makes marine turtles go: a review of metabolic rates and their consequences. J Exp Mar Biol Ecol 356:8-24

Wood SN (2001) mgcv: GAMs and Generalized Ridge Regression for R. R News 1:20-25

Zar JH (1996) Biostatistical analysis, 3rd edn. Prentice Hall, Upper Saddle River, NJ

Zug GR, Glor RE (1998) Estimates of age and growth in a population of green sea turtles Chelonia mydas from the Indian River lagoon system, Florida: a skeletochronological analysis. Can J Zool 76:1497-1506

Zug GR, Parham J (1996) Age and growth in leatherback turtles, Dermochelys coriacea (Testudines: Dermochelyidae): a skeletochronological analysis. Chelonian Conserv Biol 2:244-249

Zug GR, Rand AS (1987) Estimation of age in nesting female Iguana iguana: testing skeletochronology in a tropical lizard. Amphib-Reptilia 8:237-250

Zug GR, Wynn AH, Ruckdeschel C (1986) Age determination of loggerhead sea turtles, Caretta caretta, by incremental growth marks in the skeleton. Smithson Contrib Zool 427: $1-34$

Zug GR, Balazs GH, Wetherall JA (1995) Growth in juvenile loggerhead seaturtles Caretta caretta in the north Pacific pelagic habitat. Copeia 1995:484-487

Zug GR, Balazs GH, Wetherall JA, Parker DM, Murakawa SKK (2002) Age and growth of Hawaiian green seaturtles Chelonia mydas: an analysis based on skeletochronology. Fish Bull 100:117-127

Zug GR, Chaloupka M, Balazs GH (2006) Age and growth in olive ridley sea turtles Lepidochelys olivacea from the North-central Pacific: a skeletochronological analysis. PSZN I Mar Ecol 27:263-270

Submitted: November 28, 2008; Accepted: April 2, 2009

Proofs received from author(s): May 26, 2009 